\title{
GRAMATICALIZAÇÃO E LEXICALIZAÇÃO NO LIMITE: DEMONSTRATIVOS ROMÂNICOS
}

\author{
César Nardelli Cambraia* \\ Victor Hugo Barbosa Ramalho** \\ Sara Alves Stradioto*
}

\begin{abstract}
Resumo: As teorias que se ocupam dos processos de gramaticalização e lexicalização têm apresentado grande progresso nos últimos tempos. No domínio românico, os demonstrativos são uma categoria que desafiam os atuais postulados das referidas teorias. Analisamse aqui três fenômenos, no português e no espanhol, que assinalam a necessidade de revisão desses postulados: a lexicalização e a antilexicalização da sequência demonstrativo + indefinido; a gênese da posposição não-articulada de demonstrativos; e a adjunção de advérbios locativos a sintagmas nominais com demonstrativos.
\end{abstract} Palavras-chave: Linguística românica; gramaticalização; lexicalização; demonstrativos.

Abstract: Theories dealing with processes of grammaticalization and lexicalization have made great progress in recent times. In Romance linguistics, the demonstratives are a category that challenge current assumptions of these theories. Here three phenomena in Portuguese and in Spanish which stress the need for review of these postulates are examined: lexicalization and antilexicalization of the sequence demonstrative + indefinite; the genesis of postposition of nonarticulated demonstratives; and the adjunction of locative adverbs to noun phrases with demonstratives.

Keywords: Romance linguistics; grammaticalization; lexicalization; demonstratives.

\footnotetext{
* Universidade Federal de Minas Gerais / CNPq.

** Universidade Federal de Minas Gerais / CAPES.
} 


\section{Introdução}

As teorias que se ocupam dos processos de gramaticalização e lexicalização têm apresentado grande progresso nos últimos tempos: por um lado, verifica-se a aplicação dessas teorias a diferentes fenômenos nas mais diversas línguas; por outro lado, constata-se a preocupação de se relacionarem os dois referidos processos entre si, em prol de uma teoria mais abrangente e unitária sobre mudança linguística.

Uma categoria de especial interesse para essas discussões são os demonstrativos em línguas românicas. Trata-se de uma categoria de complexidade singular, cujo sistema passou e continua passando por reestruturações desde sua matriz latina. Observando especificamente a história da língua portuguesa e da língua espanhola, nota-se a existência de processos de mudança cujos padrões não parecem encaixar-se facilmente nos modelos teóricos para gramaticalização e lexicalização atualmente disponíveis - são eles: a lexicalização e a antilexicalização da sequência demonstrativo + indefinido; a gênese da posposição não-articulada de demonstrativos; e a adjunção de advérbios a sintagmas nominais com demonstrativos. ${ }^{1}$

\section{Gramaticalização e lexicalização}

Analisando diversas propostas de definição de gramaticalização e lexicalização com o objetivo de se estabelecer uma integração entre esses processos, Brinton \& Traugott (2005) propõem as seguintes definições:

Lexicalização é uma mudança na qual em certos contextos linguísticos os falantes usam uma construção sintática ou formação de palavra como uma nova forma portadora de

\footnotetext{
${ }^{1}$ Os três temas aqui discutidos tomam como ponto de partida, respectivamente, Cambraia (2010), Ramalho (em preparação) e Stradioto (em preparação).
} 
conteúdo com propriedades formais e semânticas que não são totalmente deriváveis ou previsíveis a partir dos constituintes da construção ou do padrão de formação de palavra. Com o passar do tempo, pode haver perda de constituência interna e o item pode tornar-se mais lexical. (BRINTON \& TRAUGOTT, 2005, p. 96; tradução nossa)

Gramaticalização é uma mudança na qual em certos contextos linguísticos os falantes usam partes de uma construção com uma função gramatical. Com o passar do tempo, o item gramatical resultante pode tornar-se mais gramatical adquirindo funções mais gramaticais e expandindo suas classes-hospedeiras. (BRINTON \& TRAUGOTT, 2005, p. 99; tradução nossa)

Esses dois processos apresentam, segundo Brinton \& Traugott (2005, p. 104-110), semelhanças e diferenças: são semelhantes por apresentarem gradualidade (mudança por pequenos passos estruturais, havendo período de convivência entre formas antigas e inovadoras), unidirecionalidade (mudança em direção a significados mais abstratos na gramaticalização e mais concretos na lexicalização), fusão (perda de fronteira vocabular), coalescência (perda de elementos fonológicos), desmotivação (perda de composicionalidade semântica) e metaforização/ metonimização (mudança fortemente vinculada ao contexto, derivada de implicaturas na situação comunicativa entre falante e ouvinte), mas são diferentes por apenas a gramaticalização apresentar descategorização (mudança de uma categoria plena para secundária), enfraquecimento (enfraquecimento de significado, tendendo ao mais geral), subjetificação (ancoragem do significado na percepção da situação pelo falante), produtividade (ocorrência em um número progressivamente amplo de categorias), frequência (aumento de frequência) e generalidade tipológica (recrutamento a partir de fontes similares em diversas línguas).

Os referidos dois processos seriam passíveis de reversão, de acordo com Brinton \& Traugott (2005, p. 104-110): a antilexicalização e a antigramaticalização. A antigramaticalização é a reversão em 
que há aumento da autonomia e perda de produtividade, passando um item de mais para menos gramatical no continuum da gramaticalização. A antilexicalização é a reversão em que há um aumento da composicionalidade, passando um item de mais para menos lexical no continuum da lexicalização.

Brinton \& Traugott (2005, p. 105) esquematizam a relação entre gramaticalização, antigramaticalização, lexicalização e antilexicalização, indicando os estágios intermediários do continuum da seguinte maneira (em tradução nossa): ${ }^{2}$

\begin{tabular}{|c|c|c|c|}
\hline \multicolumn{4}{|c|}{$<$ Antilexicalização } \\
\hline \multirow{4}{*}{$\begin{array}{l}\text { menos lexical } \\
\text { (L1) Sintagmas fixos } \\
\text { (G1) Construções gramaticais } \\
\text { menos gramatical }\end{array}$} & 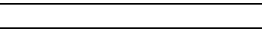 & $\longrightarrow$ & mais lexical \\
\hline & Compostos & Formas derivadas & Simples(L3) \\
\hline & Palavras funcionais & Clíticos & Flexões(G3) \\
\hline & & & is gramatical \\
\hline
\end{tabular}

FIGURA 1: Fluxograma da (anti)gramaticalização e da (anti)lexicalização

\section{Lexicalização e antilexicalização da sequência demonstrativo + indefinido}

Em diversos trabalhos tem-se defendido a unidirecionalidade de certos fenômenos de mudança linguística (HOPPER \& TRAUGOTT, 1993 p. 99-139), como a gramaticalização e a lexicalização. Entretanto, alguns estudos têm alegado existirem casos que provariam que a unidirecionalidade não é categórica (BRINTON \& TRAUGOTT, 2005, p. 103-104). Na presente seção, investiga-se um caso de interesse de mudança na história da língua portuguesa e da língua espanhola - mais especificamente, a sequência demonstrativo + indefinido $-a$ fim de verificar se se

\footnotetext{
${ }^{2}$ No fluxograma, L1 e L3 significam níveis de lexicalização; e G1 e G3, níveis de gramaticalização.
} 
trataria de um fenômeno que coloca em xeque a referida unidirecionalidade.

Desde épocas pretéritas da língua portuguesa e da língua espanhola constata-se a existência de sequência composta de demonstrativo + indefinido outro/otro - confiram-se os exemplos abaixo:

(1a) "E era senhor de Adem Xeque Hamede, o qual vezinhava com este outro Xarife por parte da terra chamada Jazem" (Ásia, João de Barros, 1552; itálico nosso)

(1b) "luego es el muftí, que no es inferior ni subjeto a este otro, sino como si hubiese dos papas" (Viaje de Turquía, Cristóbal de Villalón, ca. 1559; itálico nosso)

(2a) "ele achara naquele caminho, o qual ele não quis que aparecesse enquanto praticava com estoutro, pera ver se concordavam ambos" (Ásia, João de Barros, 1552; itálico nosso)

(2b) "iOh el diablo! Aunque estotro quiera deçir las cosas con criança y buenas palabras, no le dexaréis." (Viaje de Turquía, Cristóbal de Villalón, ca. 1559; itálico nosso)

O contraste entre os dados em (1) e em (2) permite verificar que a sequência demonstrativo + indefinido poderia ocorrer com seus elementos separados - cf. (1) - ou aglutinados - cf. (2). Aparentemente, tratar-se-ia de um fenômeno determinado pela fonética sintática (simples elisão da vogal átona final do demonstrativo), mas dados como os que se seguem mostram que se trata de uma questão mais complexa:

(3a) "toda las naus dos mouros que vinham àquele trato, do qual comércio estes outros Reis gostavam pouco, por isso, vendo as nossas naus na Índia" (Ásia, João de Barros, 1552; itálico nosso) 
(3b) “- Bien solenemente la pagan. Ansí la pagaran estos otros, y quizá no hubiera tantos vellacos." (Viaje de Turquía, Cristóbal de Villalón, ca. 1559; itálico nosso)

(4a) "navegação e comércio da Etiópia, Arábia, Pérsia e Índia, como se estoutros reinos e senhorios nomeados não se governassem per suas leis e ordenações" (Ásia, João de Barros, 1552; itálico nosso)

(4b) "daría la pena que los guardianes merescen, y a estotros la mitad della" (Viaje de Turquía, Cristóbal de Villalón, ca. 1559; itálico nosso)

Os elementos destacados em (3) indicam que, no plural, a sequência demonstrativo + indefinido poderia receber duas marcas de número: uma no demonstrativo $(e s t e+s)$ e outra no indefinido $($ outro $+s /$ otro $+s)$. Entretanto, os elementos destacados em (4) revelam que a referida sequência no plural poderia também ocorrer como uma forma aglutinada, recebendo uma marca de plural apenas no final (estoutro + s/estotro $+s$ ). Vê-se, portanto, que se trata de uma questão que vai além da fonética sintática, uma vez que, no plural, a sequência pode se comportar como uma estrutura unitária, recebendo, por isso, apenas uma marca de número.

Para melhor entender como foi a história dessas formas no português e no espanhol, fez-se uma coleta de dados relativos a essas formas na base do Corpus do Português ${ }^{3}$ (1356 dados) e do Corpus del Español ${ }^{4}$ (4364 dados). Saliente-se que a diferença de dados disponíveis decorre da natureza das bases, pois aquela compreende 45 milhões de palavras e esta 100 milhões e por isso há em torno de metade de dados do português frente aos do espanhol. Ademais, a base do português compreende dados da variedade europeia e da brasileira para os sécs. XIX e XX, enquanto a base do espanhol compreende dados da variedade europeia e

\footnotetext{
${ }^{3}$ Disponível em www.corpusdoportugues.org (DAVIES \& FERREIRA, 2006).

${ }^{4}$ Disponível em www.corpusdelespanol.org (DAVIES, 2002).
} 
das latino-americanas apenas para o séc. XX. Obtiveram-se os seguintes resultados em termos numéricos:

\section{TABELA 1}

Frequência da sequência separada e aglutinada no português e no espanhol

\begin{tabular}{l|r|r|r|r|r|r}
\hline Século & \multicolumn{3}{|c|}{ Português } & \multicolumn{3}{c}{ Espanhol } \\
\hline & Separada & Aglutinada & \multicolumn{1}{c}{ Total } & \multicolumn{1}{c}{ Separada } & Aglutinada & \multicolumn{1}{c}{ Total } \\
\hline XIII & $8(53,3 \%)$ & $7(46,7 \%)$ & $15(100 \%)$ & $1046(99,9 \%)$ & $1(0,1 \%)$ & $1047(100 \%)$ \\
\hline XIV & $58(90,6 \%)$ & $6(9,4 \%)$ & $64(100 \%)$ & $98(99,0 \%)$ & $1(1,0 \%)$ & $99(100 \%)$ \\
\hline XV & $172(91,5 \%)$ & $16(8,5 \%)$ & $188(100 \%)$ & $249(90,9 \%)$ & $25(9,1 \%)$ & $274(100 \%)$ \\
\hline XVI & $71(27,2 \%)$ & $190(72,8 \%)$ & $261(100 \%)$ & $310(30,6 \%)$ & $704(69,4 \%)$ & $1014(100 \%)$ \\
\hline XVII & $23(15,5 \%)$ & $125(84,5 \%)$ & $148(100 \%)$ & $114(18,9 \%)$ & $489(81,1 \%)$ & $603(100 \%)$ \\
\hline XVIII & $12(9 \%)$ & $122(91 \%)$ & $134(100 \%)$ & $228(60,0 \%)$ & $152(40,0 \%)$ & $380(100 \%)$ \\
\hline XIX & $264(83,8 \%)$ & $51(16,2 \%)$ & $315(100 \%)$ & $532(90,5 \%)$ & $56(9,5 \%)$ & $588(100 \%)$ \\
\hline XX & $204(88,3 \%)$ & $27(11,7 \%)$ & $231(100 \%)$ & $355(98,9 \%)$ & $4(1,1 \%)$ & $359(100 \%)$ \\
\hline
\end{tabular}

Os dados da Tabela 1 indicam claramente que houve uma nítida prevalência de sequência separada em ambas das línguas entre os sécs. XIII a XV, seguida de prevalência de aglutinada nos sécs. XVI a XVIII para o português e XVI a XVII para o espanhol, terminando com a prevalência de separada do séc. XIX em diante para o português e do séc. XVIII em diante para o espanhol. Confirma-se assim que a sequência aglutinada se difundiu e depois regrediu.

Antes de refinar a análise dos dados, convém avaliar qual é a natureza do processo de constituição da sequência aglutinada: gramaticalização ou lexicalização? Para responder a essa pergunta, devem-se retomar os já citados critérios que diferenciam esses dois processos segundo Brinton \& Traugott (2005, p. 104-110): descategorização, enfraquecimento, subjetificação, produtividade, frequência e generalidade tipológica.

No que diz respeito à descategorização, o fenômeno em análise aponta para lexicalização: não seria uma gramaticalização já que não houve mudança de uma categoria plena (como nome ou verbo) para uma secundária (como adjetivo ou preposição). A base é um demonstrativo, ao qual se associa de forma cada vez 
mais forte um indefinido, sem que o conjunto apresente indício de mudança de categoria em relação à base, que, a propósito, seria, desde o princípio, secundária.

Quanto ao enfraquecimento, o processo em estudo também sugere tratar-se de lexicalização: diferentemente da gramaticalização, em que há tendência à generalização (perda de conteúdo semântico, com expressão de um significado mais geral), a aglutinação em questão tende ao mais concreto e específico, pois consiste, na essência, no estabelecimento de diferenciação o demonstrativo simples, que codifica relação do referente com a pessoa do discurso e/ou com o espaço, passa a codificar também a ideia de diferenciação, ou seja, a presença de um outro que não é idêntico ao primeiro mas apresenta uma relação de afinidade com ele (por isso diz-se este e estoutro/estotro, e não simplesmente este e aquel (e)). A ideia de diferenciação deriva do valor etimológico do indefinido outro/otro (< lat. ALTERU-), que indicava um segundo em uma relação de dois (FARIA, 1968, p. 144).

Já em relação à subjetificação, a aglutinação em análise aponta para a gramaticalização: a ideia de diferenciação veiculada pelo indefinido é, na maioria das vezes, dependente da situação comunicativa (sobretudo no caso de uso exofórico), o que faz com que seu significado dependa da percepção da situação pelo falante.

No que tange à produtividade, o processo em discussão parece identificar-se com a lexicalização: para que se caracterizasse como produtivo (e, portanto, como um caso de gramaticalização), seria necessária sua ocorrência em um número progressivamente amplo de categorias, o que não acontece. A aglutinação de outro no português deu-se essencialmente no sistema dos demonstrativos (diferentemente do espanhol, em que atingiu também os pronomes pessoais), embora se deva registrar que teria começado a ocorrer também nos pronomes pessoais, pois, como já salientou Cambraia (2005, p. 7-30), o processo de aglutinação entre nós/vós e outros, chegou a ter início no português, mas não conseguiu implementar-se definitivamente como em espanhol (nosotros/vosostros) e em catalão (nosaltres/vosaltres). 
Quanto à frequência, o fenômeno em estudo se mostra como um caso de gramaticalização, pois há um aumento considerável de ocorrências entre os sécs. XV e XVII-XVIII: embora o número de categorias atingidas se limite basicamente ao paradigma dos demonstrativos, o número de ocorrências de sequência aglutinada frente a separada aumentou abruptamente - cf., p. ex., a passagem de $8,5 \%$ no séc. XV para $72,8 \%$ no séc. XVI no português e a de $9,1 \%$ no séc. XV para $69,4 \%$ no séc. XVI no espanhol.

Em relação à generalidade tipológica, a aglutinação em foco aponta novamente para lexicalização: não se encontrou registro de igual processo em línguas fora do universo românico e, mesmo nesse universo, não é muito frequente - apesar de ter existido no português e no espanhol (línguas em que praticamente não mais existe a sequência aglutinada), parece ter-se fixado apenas no romeno: cf. rom. cestălalt/celălalt (POPESCU, 2006, p. 216).

Em síntese, pode-se considerar que a aglutinação ocorrida na sequência demonstrativo + indefinido é essencialmente um caso de lexicalização, pois não houve mudança de categoria gramatical, ocorreu uma especificação de um valor previamente mais genérico, não atingiu um grande número de categorias e não parece ter-se manifestado em tantas línguas. Entretanto, esse processo apresenta alguns traços próprios da gramaticalização: a ancoragem na situação comunicativa e o aumento abrupto de frequência. Essa condição híbrida do processo (com traços de lexicalização e de gramaticalização) evidencia que a diferenciação estanque entre os referidos processos deve ser revista.

Voltando à análise dos dados coletados, verifica-se que a lexicalização e a antilexicalização de demonstrativo + indefinido se deram de forma muito semelhante no português e no espanhol, como evidencia o gráfico abaixo, com a frequência das formas aglutinadas: 


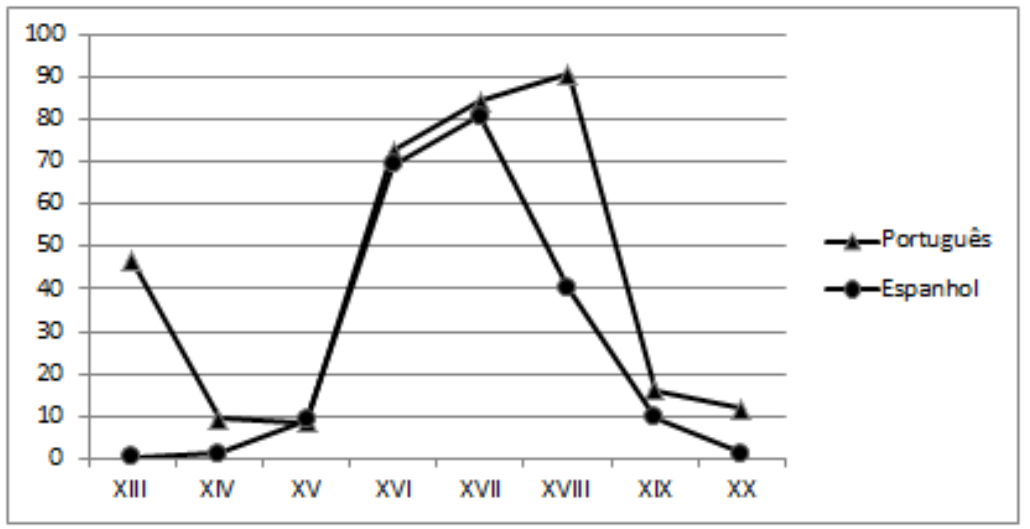

GRÁFICO 1: Frequência (\%) de sequência aglutinada no português e no espanhol

Nota-se no gráfico que o aumento da sequência aglutinada foi igualmente abrupto no português e no espanhol e na mesma época (séc. XVI). As duas línguas se diferenciam pela época de regressão da sequência aglutinada (séc. XIX no português e séc. XVIII no espanhol), pela intensidade (abrupto no português e mais gradual no espanhol), pelo pico (mais alto no português do que no espanhol) e pelos resquícios (maior no português do que no espanhol). Quanto aos resquícios, convém assinalar que a sequência aglutinada se restringe sobretudo às variedades europeias (no português, 50\% na variedade lusitana frente a $6,5 \%$ na brasileira no séc. XIX e, respectivamente, 26,1\% frente 2,8\% no séc. XX; no espanhol, 1,1\% na variedade peninsular ${ }^{5}$ frente a nenhuma ocorrência nas variedades latino-americanas no séc. XX).

Uma estratégia para avaliar a motivação para esses dois processos de mudança (a lexicalização e a antilexicalização) é examinar em que ponto do sistema se iniciaram. Convém analisar a frequência da sequência aglutinada ao longo da faixa de tempo

\footnotetext{
${ }^{5}$ Nos quatro únicos dados de aglutinada no espanhol no séc. XX, trata-se de dados metalinguísticos (comentários sobre os demonstrativos), o que sugere que nesse século já não era mais usada.
} 
estudada segundo, pelo menos, quatro critérios: forma (este $[=\mathrm{F} 1] / e s(s) e[=\mathrm{F} 2] /$ aquel $(e)[=\mathrm{F} 3]$ e flexões), número (singular/ plural), gênero (masculino/feminino/neutro) e tipo de $S N$ (margem/núcleo nominal). A relevância de trabalhar-se com diferentes critérios deve-se ao fato de que as mudanças se propagam de forma gradual, atingindo primeiramente algumas categorias e depois outras (NARO \& LEMLE, 1977, p. 268).
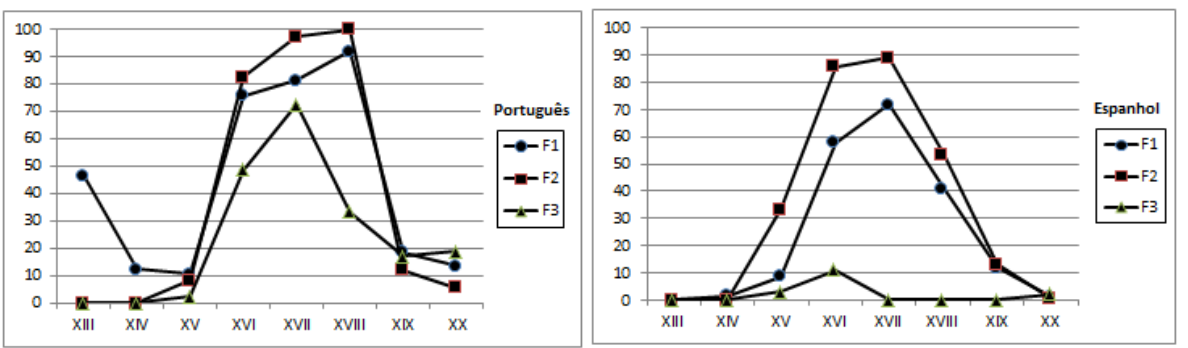

GRÁFICOS 2a e 2b: Frequência (\%) de sequência aglutinada no português e no espanhol, por forma

Os Gráficos 2a e 2b deixam perceber certas regularidades em ambas as línguas: (a) F1 foi a primeira forma a apresentar sequência aglutinada; (b) nos períodos de prevalência geral de aglutinada (sécs. XVI-XVIII) manteve-se a hierarquia F2 > F1 > F3; e (c) F3 foi a última forma a apresentar aglutinada e a primeira em que a aglutinada regrediu (cf. dados do séc. XVIII para o português e do séc. XVII para o espanhol).
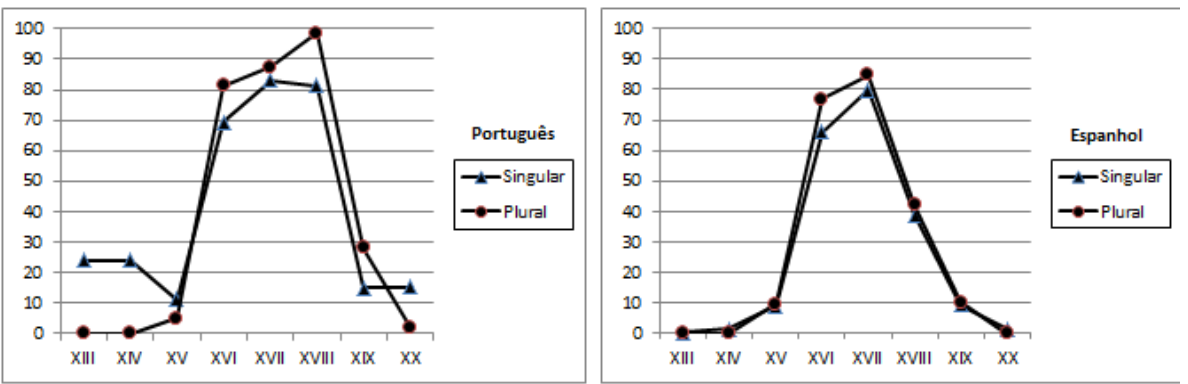

GRÁFICOS 3a e 3b: Frequência (\%) de sequência aglutinada no português e no espanhol, por número 
Os Gráficos 3a e 3b deixam ver novas regularidades em ambas as línguas: (a) a sequência aglutinada aparece pela primeira vez no singular; e (b) nos períodos de prevalência de aglutinada (sécs. XVI-XVIII) há leve predominância no plural. Há, porém, diferenças: (a) no português, a aglutinada no singular começou a regredir antes de no plural e, no espanhol, a regressão foi simultânea; e (b) no português, houve mais resquício (cf. séc. XX) de forma no singular do que no plural, enquanto, no espanhol, a regressão atinge os dois números na mesma proporção.
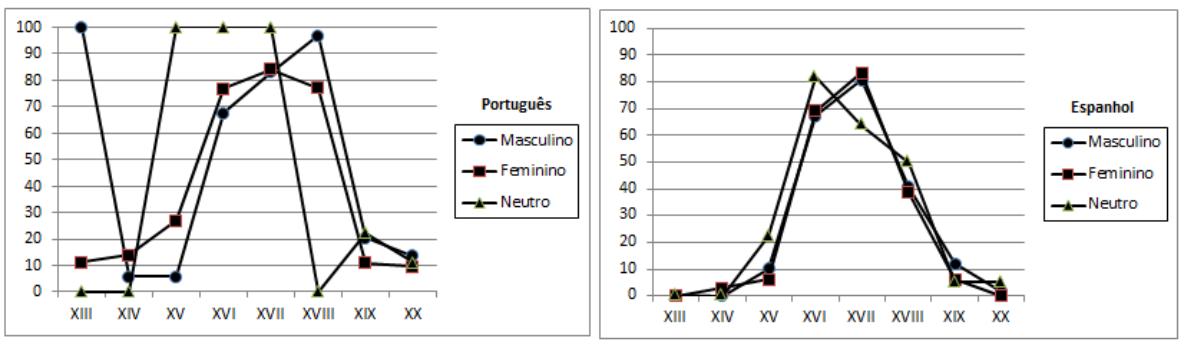

GRÁFICOS 4a e 4b: Frequência (\%) de sequência aglutinada no português e no espanhol, por gênero

Os Gráficos 4a e 4b permitem verificar que a sequência aglutinada tem especial relação com o gênero masculino no início (no português é o mais frequente no séc. XIII e no espanhol é o único que apresenta aglutinada no séc. XIII, com 0,3\%), mas depois o gênero feminino quase que se emparelha com o masculino (o emparelhamento é mais nítido no espanhol do que no português). Quanto ao neutro em ambas as línguas, é o último a apresentar aglutinada, aparecendo pela primeira vez só no séc. XV (já com alta frequência no português), e é o primeiro gênero no qual as aglutinadas começam a desaparecer (cf. séc. XVIII para português e XVII para o espanhol). 

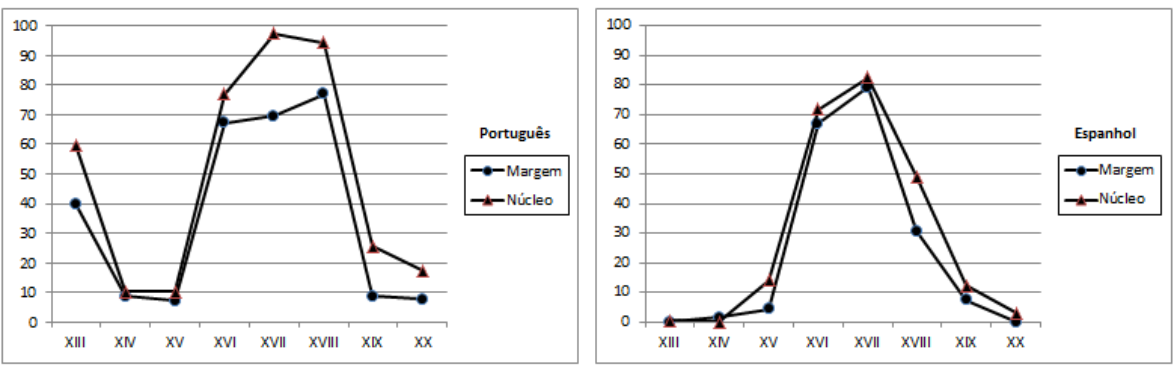

GRÁFICOS 5a e 5b: Frequência (\%) de sequência aglutinada no português e no espanhol, por tipo de SN

Os Gráficos 5a e 5b deixam notar em relação a ambas as línguas que a sequência aglutinada de forma geral é mais frequente em posição de núcleo do que de margem tanto no início quanto ao longo do período em que foi prevalente, mas a diferença de preferência por posição não é tão discrepante.

O cruzamento dos dados acima arrolados permite verificar que a sequência aglutinada já existia desde o séc. XIII, tendo surgido provavelmente em primeiro lugar em F1, no singular, no masculino e em posição de núcleo (toma-se aqui a alta frequência da sequência aglutinada em uma dada categoria como indicador de seu contexto de origem). Pode-se considerar que a sequência aglutinada tenha sua origem em um processo fonológico de elisão: certamente seu começo em F1 no singular no masculino deve estar relacionado à instabilidade de vogal $e$ em posição final no português (WILLIAMS, 1991, p. 59-60) e no espanhol arcaicos (LLOYD, 1989, p. 337-344), instabilidade esta que praticamente não atingia o - $a$ (da forma feminina) e o -o(da forma neutra) na mesma posição.

$\mathrm{O}$ passo seguinte do processo terá sido a reanálise da sequência aglutinada formada por processo fonológico de elisão como um alomorfe composto da base (est- seria a base simples e estoutr-/estrot- seria uma base composta), razão pela qual a flexão no plural levaria à anexação do morfema $-\boldsymbol{s}$ apenas no final do composto, após a marca de gênero (cf. estoutr $+o+s /$ estotr $+o+s$ ). Essa reanálise terá ocorrido de forma abrupta (cf., no Gráfico 1, o 
salto na frequência da aglutinada na passagem do séc. XV para XVI no português e no espanhol), aspecto que, como já dito, seria mais próprio de um processo de gramaticalização do que de lexicalização. É justamente a reanálise que terá aberto as portas para a difusão para os demais gêneros (feminino e neutro) e para as demais formas (F2 e F3) no processo.

Já as etapas do processo de antilexicalização não são tão nítidas. Primeiramente, nota-se uma discrepância entre português e espanhol: naquele, foi abrupta na passagem do séc. XVIII para XIX e, neste, foi relativamente gradual na passagem do séc. XVII para XIX, ou seja, no espanhol começou antes e foi gradual. É bem provável que a regressão esteja relacionada a $\mathrm{F} 3$, forma em que a sequência aglutinada apareceu depois, sempre teve menor frequência e regrediu primeiro.

Por um lado, o papel favorecedor de F1 na lexicalização pode ser justificado com base na sua alta frequência frente às duas outras formas:

\section{TABELA 2}

Distribuição da sequência demonstrativo + indefinido por forma e por século

\begin{tabular}{|c|c|c|c|c|c|c|c|c|}
\hline \multirow[b]{2}{*}{ Século } & \multicolumn{4}{|c|}{ Português } & \multicolumn{4}{|c|}{ Espanhol } \\
\hline & F1 & F2 & F3 & Total & F1 & F2 & F3 & Total \\
\hline XIII & 15 (100\%) & - & - & $15(100 \%)$ & $929(88,7 \%)$ & $26(2,5 \%)$ & $92(8,8 \%)$ & $1047(100 \%)$ \\
\hline XIV & $48(75 \%)$ & $1(1,6 \%)$ & $15(23,4 \%)$ & $64(100 \%)$ & $69(69,7 \%)$ & $3(3,0 \%)$ & $27(27,3 \%)$ & $99(100 \%)$ \\
\hline $\mathbf{X V}$ & $133(70,7 \%)$ & $12(6,4 \%)$ & $43(22,9 \%)$ & $188(100 \%)$ & $230(83,9 \%)$ & $12(4,4 \%)$ & $32(11,7 \%)$ & $274(100 \%)$ \\
\hline XVI & $182(69,7 \%)$ & & $39(14,9 \%)$ & $261(1$ & $500(49,3 \%)$ & $478(47,1 \%)$ & $36(3,6 \%)$ & 1014 \\
\hline XVII & $86(58,1 \%)$ & $40(27 \%)$ & $22(14,9 \%)$ & $148(100 \%)$ & $225(37,3 \%)$ & $367(60,9 \%)$ & $11(1,8 \%)$ & $603(100 \%)$ \\
\hline XVIII & $128(95,5 \%)$ & $3(2,2 \%)$ & $3(2,2 \%)$ & $134(100 \%)$ & $237(62,4 \%)$ & $99(26,0 \%)$ & $44(11,6 \%)$ & $380(100 \%)$ \\
\hline $\mathbf{X I X}$ & $129(41 \%)$ & $98(31,1 \%)$ & $88(27,9 \%)$ & $315(100 \%)$ & $253(43,0 \%)$ & $197(33,5 \%)$ & $138(23,5 \%)$ & $588(100 \%)$ \\
\hline & $44(19 \%)$ & $108(46,8 \%)$ & $79(34,2 \%)$ & $231(100 \%)$ & $177(49,3 \%)$ & $134(37,3 \%)$ & $48(13,4 \%)$ & $359(100 \%)$ \\
\hline
\end{tabular}

Por outro lado, o suposto papel favorecedor de F3 na antilexicalização dificilmente pode ser justificado com base na sua frequência, quase sempre marginal. É fato, porém, que a antilexicalização ocorreu no português justamente em época que F3 entrou em uma tendência crescente de frequência (séc. XIX no português e XVIII no espanhol). 
É bem possível que a antilexicalização tenha sido viabilizada pela persistência da variante conservadora (sequência separada) mesmo quando a inovadora (sequência aglutinada) se tornou prevalente entre os sécs. XVI-XVIII. Nesse caso, então, a antilexicalização estudada seria, na verdade, uma regressão da variante inovadora. Talvez a questão da unidirecionalidade se aplique melhor a fenômenos em que a variante conservadora tenha desaparecido completamente do sistema.

\section{Gênese da posposição não-articulada de demonstrativos}

Para se compreender mais profundamente os princípios que regem as variações tipológicas na gramática das línguas, Givón (2001, v. I, p. 23) defende que é insuficiente o desenvolvimento de uma análise meramente sincrônica dos fenômenos linguísticos, uma vez que é também de fundamental importância para tal objetivo o acompanhamento do processo diacrônico de gramaticalização envolvido. Sendo assim, apenas a observação histórica poderá trazer à tona as verdadeiras causas e consequências do surgimento de formas inovadoras nas línguas, já que os processos de mudança ocorreriam de forma gradativa até chegarem ao momento em que se fixam.

Embora a definição de gramaticalização de Brinton \& Traugott (2005), já apresentada na seção 2 acima, se baseie na ideia de "partes de uma construção" (e não apenas item lexical), as quais assumiriam função gramatical no curso do processo em questão, salta aos olhos o fato de que pouco ou nada se fala quanto a processos em que essas "partes de uma construção" passam por reordenação dos seus elementos internos, gerando uma nova estrutura gramatical. Na presente seção, analisa-se um caso justamente desse tipo especial de gramaticalização: trata-se da gênese da posposição não-articulada de demonstrativos no português e no espanhol.

Comparem-se os dados a seguir: 
(5) "Se o Publico illustrado fizer o devido apreço deste meu primeiro trabalho original, que vai ser posto debaixo das suas vistas, tenciono fazel-o seguir de outro não menos interessante, qual é o que terá por titulo Lições Elementares de Poetica Nacional, e de Critica Litteraria, obras estas que se achão já promptas para sahir igualmente a lume." (Lições elementares de eloquencia nacional, Francisco Freire de Carvalho, 1834; itálico nosso)

(6) "Era la concurrencia numerosa y compuesta de lo más granado que a la sazón encerraba Londres de pares célebres, así del partido ministerial como del de la oposición, de miembros de la Cámara de los Comunes de ambas opuestas parcialidades; de otros ingleses de distinción, de extranjeros de no menos nota, y de casi todos los diplomáticos entonces residentes o de paso en la Gran Bretaña, razón esta última porque estaba yo entre personajes de tanto brillo." (Memorias de D. Antonio Alcalá Galiano, Antonio Alcalá Galiano, 184749 [1886]; itálico nosso)

Nos dados acima, ambos da $1^{\mathrm{a}}$ met. do séc. XIX, é possível verificar que os demonstrativos ocorrem pospostos ao nome tanto em português quanto em espanhol: trata-se dos dados mais antigos desse tipo sintático encontrados até o momento através de busca nas já referidas bases do Corpus do Português e do Corpus del Español (trabalha-se nesta seção apenas com a variedade europeia dessas duas línguas, com dados de língua falada e de língua escrita conjuntamente). Os resultados aqui obtidos reiteram a afirmação de Cambraia $(2009$, p. 24) de que se trata de um tipo relativamente recente no português e sugerem que o mesmo se dá em relação ao espanhol.

É importante salientar, porém, que, como apurado por Alexander (2007, p. 181 e 213), há um tipo sintático correlato no espanhol que é bem mais antigo - trata-se de posposição de demonstrativo em SN com artigo, existente desde o século XIV: 
(7) "La tenor de la carta(s) esta fue que por todas las tierras y por los pueblos sobre que auia seynnorio el rey assuero souiessen los Judios apareiados pora prender vengança de sus enemigos." (Biblia latina, 1300-1400; itálico nosso $)^{6}$

$\mathrm{Na}$ presente seção aborda-se, porém, apenas o primeiro tipo sintático aludido, a que se chamará aqui de posposição nãoarticulada (por oposição ao segundo tipo, a que se pode chamar de posposição articulada). É interessante notar, entretanto, que a posposição de demonstrativo não é privativa do português e do espanhol: aparece no catalão (BRUCART, 2008, v. 2, p. 1494-1496) e no romeno (POPESCU, 2006, p. 218), mas, nestes dois últimos, sempre articulada.

Naturalmente a primeira questão que se coloca é como se deu a emergência da posposição não-articulada. No que se refere ao português, Cambraia (2009, p. 29) sugeriu que derive de "reanálise de estruturas em que predicativo (substantivo) e sujeito (demonstrativo) aparecem em contato e nessa ordem (como em exclamações), as quais acabam por ser interpretadas como um só sintagma nominal". 7 Assim, uma estrutura como "Que homem este!" (Os fidalgos da casa mourisca, Júlio Dinis, 1871) teria possibilitado o seguinte trajeto de reanálise: [[Que homem][este]] > [Que [homem este]]> [homem este]. Dessa reanálise surgiria então a possibilidade de posposição, como no dado abaixo, extraído do mesmo texto da estrutura comentada acima:

\footnotetext{
${ }^{6}$ Dado reproduzido de Alexander (2007, p. 141).

${ }^{7}$ Não raramente encontra-se interpretação de que estruturas exclamativas como esta são simplesmente casos de posposição de demonstrativo (BECHARA, 1978, p. 267; ROCA URGELL, 1996, p. 129), mas trata-se de estrutura que, muito provavelmente em sua origem, consistia em exclamativa com verbo de ligação (p. ex., "Que homem é este!"), o qual foi se tornando opcional a ponto de quase não mais aparecer, dando justamente espaço para a reanálise que aqui se defende ter acontecido.
} 
(8) "Embalava-o a vaidosa persuasão de que havia impressionado Bertha. Tinha Mauricio este defeito de suppôr que eram prontas e profundas as impressões que produzia no animo das mulheres. Defeito este vulgar e que ainda não é dos que dão de si mais sérias consequências." (Os fidalgos da casa mourisca, Júlio Dinis, 1871; itálico nosso)

Diante da existência da posposição articulada no espanhol, poder-se-ia imaginar que a posposição não-articulada derivaria da articulada: neste caso, seria necessário supor que a posposição não-articulada do português tenha sido empréstimo do espanhol, já que a articulada não parece ocorrer no português. Como, nos dados mais antigos da posposição não-articulada do português e do espanhol, há uma antecedência temporal daquele sobre este (antecedência relativa, diga-se de passagem, já que pode decorrer da seleção dos textos que fazem parte das duas bases consultadas e, além disso, é temporalmente muito próxima, com diferença de aprox. apenas 15 anos), vale a pena tomar como ponto de partida a hipótese de que a posposição não-articulada seja um tipo com formação independente da posposição articulada. Ademais, há certas especificidades que particularizam a posposição nãoarticulada. No que diz respeito ao espanhol, Roca Urgell (1996, p. 129) assinala que se caracteriza por exigir a presença de um complemento que se siga ao demonstrativo (uma oração relativa, uma oração comparativa ou um sintagma preposicional) e por empregar-se sempre como aposição a um núcleo nominal, formando sintagmas nominais que nunca aparecem em posição argumental dentro da oração; já Alexander (2007, p. 108) salienta tratar-se de fenômeno representativo de registros mais altos (i. é, padrão culto). Já quanto ao português, as informações são muito menos precisas: Bechara (1978, p. 267) sugere que a posposição ocorre em situação de ênfase, sobretudo se o demonstrativo se referir a pensamento já expresso; Cunha \& Cintra (1985, p. 324) dizem apenas que serve "para melhor especificar o que se disse anteriormente"; e Pavani (1987, p. 33) considera que seja um 
padrão próprio de linguagem escrita em função de não ter encontrado nenhuma ocorrência em seu corpus do NURC de São Paulo. ${ }^{8}$

No contexto do presente trabalho, importa interpretar o fenômeno da gênese da posposição não-articulada de demonstrativos em relação ao processo de gramaticalização: trata-se de um processo de gramaticalização? Levando-se em conta a já mencionada definição de Briton \& Traugott (2005), poder-se-ia dizer, em tese, que sim, pois o fenômeno envolve uma construção (sintática) que adquire uma função gramatical específica. Entretanto, os critérios de análise de Briton \& Traugott (2005) não parecem ser plenamente adequados para descrever as particularidades desse processo.

Primeiramente, para que haja gradualidade seria de se esperar que a posposição não-articulada tivesse começado por pequenos passos estruturais. Levando em conta a estrutura em questão, não há por ora evidência de gradualidade quanto à ordem no SN, pois há apenas duas opções: anteposto (padrão original) e posposto (padrão inovador). Mas pode-se considerar que a gradualidade se expressaria nos tipos de estrutura em que a posposição não-articulada apareceria: neste caso, seria de se esperar origem em um padrão estrutural específico e expansão para outros, mas os dados não permitem ver com clareza um tal processo de expansão. $\mathrm{Na}$ base do português, identificaram-se 54 casos de posposição não-articulada ( 7 no séc. XIX e 47 no séc. XX); e na do espanhol, apenas 8 ( 2 no séc. XIX e 6 no séc. XX).Os padrões de organização do SN foram os seguintes:

\footnotetext{
${ }^{8}$ Em estudo prévio (CAMBRAIA, 2009, p. 21-22) a partir de quatro bases do NURC [Salvador, Rio de Janeiro, São Paulo e Porto Alegre, com um total conjunto de 430 dados], identificaram-se, porém, duas ocorrências de posposição não-articulada nos dados do NURC do Rio de Janeiro (dados de língua falada).
} 


\section{TABELA 3}

Frequência de posposição não-articulada por tipo de SN no português e no espanhol europeus

\begin{tabular}{l|c|c|c|c}
\hline & \multicolumn{2}{|c|}{ Português europeu } & \multicolumn{2}{c}{ Espanhol europeu } \\
\hline Padrão & Séc. XIX & Séc. $\mathbf{X X}$ & Séc. XIX & Séc. XX \\
\hline $\mathrm{N}+$ dem. + or. relativa & $7(100 \%)$ & $30(63,8 \%)$ & - & $2(33,3 \%)$ \\
\hline $\mathrm{N}+$ dem. + SAdj. & - & $14(29,8 \%)$ & - & - \\
\hline $\mathrm{N}+$ dem. + SPrep. & - & $2(4,3 \%)$ & - & - \\
\hline $\mathrm{N}+$ dem. + SAdj. + or. subordinada & - & $1(2,1 \%)$ & $1(50 \%)$ & - \\
\hline $\mathrm{N}+$ dem. + SAdj. + or. relativa & - & - & $1(50 \%)$ & $4(66,7 \%)$ \\
\hline Total & $7(100 \%)$ & $47(100 \%)$ & $2(100 \%)$ & $6(100 \%)$ \\
\hline
\end{tabular}

É possível verificar pelos dados da tabela acima que no português houve um ampliação do número de diferentes tipos de SN em que a posposição não-articulada ocorre (de 1 tipo no séc. XIX para 4 no séc. XX) e no espanhol houve numericamente uma manutenção ( 2 no séc. XIX e 2 no séc. XX), embora não sejam exatamente as mesmas duas categorias. Enquanto os dados do português sugerem efetivamente um fenômeno de gramaticalização, já que a estrutura se tornou mais produtiva, sendo utilizada em diferentes contextos no séc. XX; já os dados do espanhol não evidenciam processo igual.

No que diz respeito à unidirecionalidade, parece pertinente considerar que de fato tenha havido uma tendência a significado mais abstrato, pois a ideia de "proximidade no fluxo do discurso" expressa pelo uso de F1 na posposição teria se apagado em favor da ideia mais abstrata de simplesmente "já mencionado" (sem identificação de sua distância no fluxo do discurso), razão pela qual passaria a ocorrer posposição também com F2 (forma historicamente associada à ideia de anáfora - cf. sua origem latina em ipse). Veja-se abaixo a distribuição de formas na posposição não-articulada: 


\section{TABELA 4}

Frequência de posposição não-articulada por forma no português e no espanhol europeus

\begin{tabular}{l|c|r|c|c}
\hline & \multicolumn{2}{|c|}{ Português europeu } & \multicolumn{2}{c}{ Espanhol europeu } \\
\hline Forma & Séc. XIX & Séc. XX & Séc. XIX & Séc. XX \\
\hline F1 & $7(100 \%)$ & $8(17 \%)$ & $2(100 \%)$ & $6(100 \%)$ \\
\hline F2 & - & $39(83 \%)$ & - & - \\
\hline F2 & - & - & - & - \\
\hline Total & $7(100 \%)$ & $47(100 \%)$ & $2(100 \%)$ & $6(100 \%)$ \\
\hline
\end{tabular}

Os dados sugerem que o espanhol é muito mais conservador, pois restringiria a posposição não-articulada a F1. É interessante assinalar que, das 8 ocorrências apuradas para o espanhol, em 6 há no SN com demonstrativo posposto o adjetivo último $(a)$, tal como ocorre na totalidade dos dados do séc. XIX para essa língua - confira-se como exemplo o dado em (6) acima apresentado: tal fato confirma de certa forma que, no espanhol, $o$ significado de "proximidade no fluxo do discurso" persiste no novo tipo sintático e, provavelmente por isso, bloqueia/dificulta a expansão para F2 e F3.

Quanto ao critério da fusão, poder-se-ia dizer que procede em termos para o fenômeno em questão, pois no corpus não ocorreu nenhum caso de intercalação de elemento entre o núcleo do SN e o demonstrativo posposto, indicando assim um alto grau de coesão sintática (uma tendência à fusão). Não há propriamente a fusão em si, uma vez que a fronteira vocabular não foi apagada, pois, no plural, há sempre a presença do morfema de número ao final do nome e do demonstrativo (diferentemente do caso estudado na seção 3, em que houve fusão entre demonstrativo e indefinido, aparecendo, por isso, apenas uma marca de plural ao final do conjunto).

No que tange à coalescência, não se verifica nenhuma perda de elemento fonológico, provavelmente pelo fato de os dados de língua escrita (modalidade em que a posposição nãoarticulada aparece preferencialmente) não serem totalmente transparentes em relação a esse tipo de processo. 
A questão da desmotivação parece retomar a questão da unidirecionalidade: com a abstratização do significando da posposição (de "perto" para "já mencionado"), acabaria havendo uma perda de composicionalidade, pois o valor original expresso especificamente pelo demonstrativo ficaria enfraquecido, tornando-se dependente da construção nome + demonstrativo como um todo.

Por fim, não parece haver a chamada metaforização/ metonimização, pois a identificação do referente expresso pela construção nome + demonstrativo é dependente do contexto intralinguístico (referente mencionado antes) e não do contexto extralinguístico (situação comunicativa). A posposição nãoarticulada é usada estritamente com função endofórica anafórica, cuja interpretação depende apenas da seção anterior do discurso, não tendo vínculo evidente com a situação de comunicação.

Passando agora aos aspectos que seriam específicos da gramaticalização (em contraste com os da lexicalização), verificase, primeiramente, que não há uma propriamente uma descategorização, pois os demonstrativos continuam como tal (trata-se de uma categoria secundária), apesar de se constatar que o tipo sintático novo apresenta muito mais limitações do que o tipo antigo (anteposição): basta atentar para o fato já aludido de que, ponto de vista semântico, a posposição não-articulada se restringe à função anafórica. Há, por outro lado, enfraquecimento, pois, como já se assinalou, o significado mais concreto de "proximidade" no fluxo do discurso dá lugar ao mais abstrato "já mencionado" (perde-se assim o sema relativo à ideia de espaço). Não parece haver a subjetificação, pois a posposição é usada estritamente com função endofórica anafórica, cuja interpretação depende apenas da seção anterior do discurso, não tendo vínculo evidente com a situação de comunicação. Quanto à produtividade, os dados do português são mais transparentes em relação a isso, pois a posposição não-articulada parece ter começado em F1 e depois teria se expandido para $\mathrm{F} 2$, embora no espanhol não se verifique o mesmo nos dados. É interessante salientar, porém, que 
a posposição de elementos no SN é possível em relação a algumas outras categorias no português e no espanhol, tais como possessivos e quantificadores: há que se verificar se a mobilidade de classes como essas pode ter influenciado na gramaticalização da posposição de demonstrativos. No que se refere à frequência, consta-se que de fato houve um aumento no número de ocorrências do séc. XIX para o XX em ambas as línguas, embora, saliente-se, a posposição não-articulada seja um fenômeno bastante raro nessas línguas. Por fim, a questão da generalidade tipológica é complexa: por um lado, há no português e no espanhol, o que sugeriria que não é um fenômeno isolado; mas, como já salientado, não parece haver em outras línguas românicas, exceto no caso de posposição articulada, existente no catalão e no romeno.

Em síntese, novamente se constata um fenômeno de mudança linguística que não parece se encaixar facilmente no modelo de descrição da gramaticalização de Briton \& Traugott (2005), pois as características do fenômeno de gramaticalização ora são verificadas no fenômeno analisado (a saber, unidirecionalidade, fusão, desmotivação, enfraquecimento, produtividade e frequência) ora não o são (a saber, gradualidade, coalescência, metaforização/metonimização, descategorização, subjetificação e generalidade tipológica).

Pôde-se constatar, através da análise diacrônica das ocorrências dos demonstrativos pospostos aqui realizada, que a reorganização do posicionamento dos itens lexicais em prol da expressão de uma nova função no discurso também pode ser inserida no quadro teórico da gramaticalização (ainda que, como se viu acima, não seja tarefa simples diferenciar fenômenos de gramaticalização e de lexicalização), uma vez que o ordenamento inovador dos componentes do sintagma produziu um novo recurso gramatical e as estruturas se fixaram de modo a serem usadas para reproduzir matizes semânticos diferentes do ordenamento canônico (ou seja, anteposição). Os modelos de descrição de gramaticalização disponíveis, porém, não parecem dar conta das especificidades desse processo. 


\section{Adjunção de advérbios locativos a sintagmas nominais com demonstrativos}

Como ressaltado por Cambraia (2009, p. 30), há uma tendência ao binarismo nos sistemas de demonstrativos do português brasileiro (com prevalência de F2 e F3) e do espanhol mexicano (com prevalência de F1 e F2). Segundo Câmara Jr. (1971, p. 329-330), essa tendência no português do Brasil favoreceria a combinação de demonstrativos com (advérbios) locativos para especificar diferenças de significado obliteradas pela variação entre este e esse, processo que Roncarati (2003, p. 144) chama de mecanismo compensatório. A adjunção de demonstrativos, porém, não se restringe às duas variedades românicas citadas: Cambraia $\&$ Bianchet (2008, p. 31-34) apresentam exemplos em diversas línguas românicas, destacando-se, dentre elas, o francês, em que tal padrão já se encontra profundamente gramaticalizado.

Diante desse quadro, pode-se aventar a hipótese de que haveria uma unidirecionalidade nas mudanças dos sistemas de demonstrativos: todos tenderiam a seguir o mesmo trajeto de redução do número de termos do sistema, acompanhado da gramaticalização de adjunção de advérbio locativo.

Para avaliar se, de fato, essa é uma tendência geral ou se haveria diferentes caminhos no processo de redução do número de termos do sistema de demonstrativos, realizou-se uma pesquisa experimental com falantes do português de Belo Horizonte (PBH) e do espanhol da Cidade do México (ECM): 50 informantes para cada variedade ( 25 por gênero, todos de 20 a 35 anos) foram instruídos a preencher um questionário adaptado de Milano (2007, p. 44-47). O questionário continha 12 quadros simulando diferentes interações com dois bonecos que representavam os interlocutores e uma bola. Os sujeitos deveriam considerar que o falante - no caso, o boneco localizado imediatamente abaixo de um balão - deveria pedir a bola ao ouvinte completando a frase 
"Me dá...". ${ }^{9}$ As interações foram baseadas nas díades da conversação de Jungbluth (2005, p. 219-222), que consideram o controle da orientação dos interlocutores e do tipo de referente como condição fundamental para qualquer estudo de dêixis. Para atender a essa condição, a posição dos três elementos (falante - ouvinte - bola) mudava conforme o quadro. A coleta de dados foi realizada em dezembro de 2010 e janeiro de 2011 em Belo Horizonte, e em fevereiro e março de 2011 na Cidade do México.

Considerando primeiramente o tipo de determinante que acompanhou o substantivo no preenchimento das lacunas dos quadros dos questionários, obtiveram-se os seguintes resultados:

\section{TABELA 5}

Frequência por tipo de determinante

\begin{tabular}{c|c|c|c|c|c}
\hline & Artigo & Demonstrativo & Possessivo & Outro & Total \\
\hline PBH & $214(35,7 \%)$ & $362(60,5 \%)$ & $1(0,2 \%)$ & $23(3,8 \%)$ & $600(100 \%)$ \\
\hline ECM & $363(60,5 \%)$ & $157(26,2 \%)$ & $59(9,8 \%)$ & $21(3,5 \%)$ & $600(100 \%)$ \\
\hline
\end{tabular}

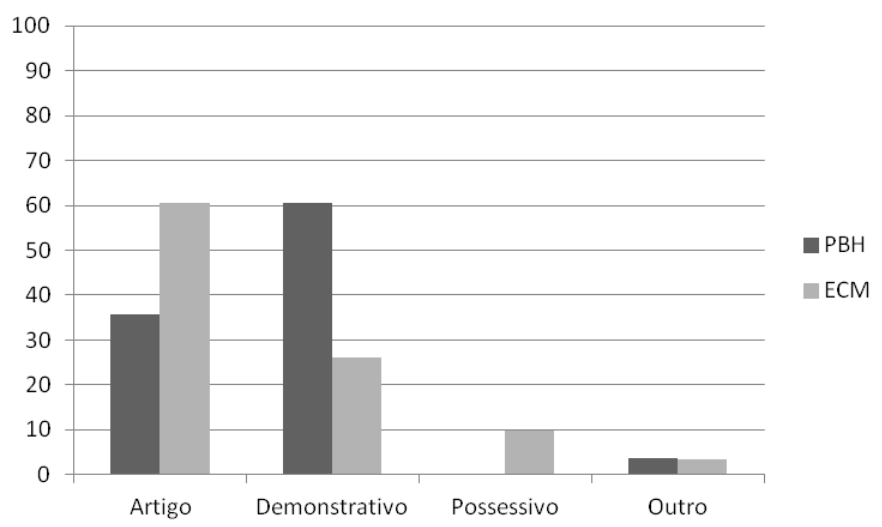

GRÁFICO 6: Frequência (\%) de tipo de determinante

\footnotetext{
${ }^{8}$ Adotou-se na tradução do questionário para o português o estilo informal, compatível com modalidade oral, por isso há o uso de próclise (Me dá...) e não de ênclise (Dá-me...), como normativamente se exige em estilo formal na modalidade escrita.
} 
A Tabela 5 e o Gráfico 6 permitem verificar que os demonstrativos são a forma preferida pelos falantes do $\mathrm{PBH}$ para a indicação de elementos no mundo (a dêixis) enquanto os falantes do ECM preferem construções com artigo para realizar a mesma função. Curiosamente, observa-se que falantes do ECM escolhem ainda o possessivo átono (todas as referências às formas de possessivo dizem respeito às átonas, uma vez que não houve ocorrências de formas tônicas) em quase $10 \%$ das vezes. Esse dado indica a insuficiência das explicações das gramáticas tradicionais do espanhol, que consideram como única função dessas partículas a expressão de posse ou pertencimento (LLORACH, 2000, p.118). O gráfico 6 sugere que algum fator no sistema do ECM reduziria a produtividade dos demonstrativos como formas dêiticas espaciais.

No que se refere aos demais elementos presentes no sintagma nominal no preenchimento das lacunas dos quadros dos questionários, os dados foram divididos em duas categorias: determinantes simples e determinantes especificados. Consideraramse do tipo simples ocorrências como "Me dá $a$ bola" (artigo simples = AS), "Dame este balón por favor" (demonstrativo simples = DS) e "Dame tu pelota" (possessivo simples = PS).$^{10}$ Consideraram-se do tipo especificado ocorrências como "Me dá a bola atrás de você"/"Dame la pelota que tienes enfrente" (artigo especificado = $\mathrm{AE})$ e "Me dá aquela bola lá" (demonstrativo especificado = DE). Os valores apurados foram:

\footnotetext{
${ }^{10}$ Como se pode ver pela tabela abaixo, não houve ocorrência de possessivo especificado (PE).
} 
TABELA 6

Frequência de determinantes simples $\times$ especificados

\begin{tabular}{l|c|c|c|c|c|c}
\hline & AS & AE & DS & DE & PS & PE \\
\hline PBH & $103(48,1 \%)$ & $111(51,9 \%)$ & $181(50,0 \%)$ & $181(50,0 \%)$ & $1(100 \%)$ & - \\
\hline Total & $214(100 \%)$ & $362(100 \%)$ & \multicolumn{2}{c}{$1(100 \%)$} \\
\hline ECM & $163(44,9 \%)$ & $200(55,1 \%)$ & $146(93,0 \%)$ & $11(7,0 \%)$ & $59(100 \%)$ & - \\
\hline Total & \multicolumn{2}{|c|}{$363(100 \%)$} & \multicolumn{2}{c|}{$157(100 \%)$} & $59(100 \%)$ \\
\hline
\end{tabular}

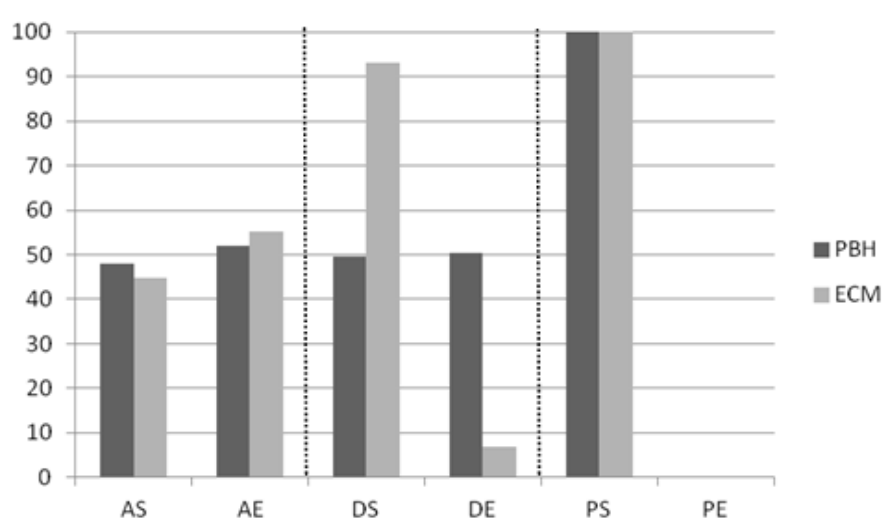

GRÁFICO 7: Frequência (\%) de determinantes simples $\times$ especificados

Observe-se que o uso de AS e o de AE no PBH são quase equivalentes, enquanto no ECM o uso de AE é levemente mais frequente $( \pm 10 \%$ de diferença) do que de AS. O artigo parece ser um determinante menos exigente e mais versátil: é utilizado tanto sozinho (AS) quanto acompanhado (AE). Quando usado como determinante simples, fica dependente do contexto situacional a interpretação do enunciado, sendo dependente, portanto, da pragmática. Quando usado como determinante acompanhado por especificador, atua com mais força a semântica: a interpretação do enunciado é obtida a partir da interpretação do significado de formas linguísticas (no caso, os especificadores). Quanto ao padrão de comportamento dos demonstrativos, categoria em que as duas variedades linguísticas apresentam grande diferença, percebemos 
que as ocorrências de DS e DE são semelhantes apenas no PBH, pois no ECM, quase não se faz uso de DE. Nota-se ainda que o uso do possessivo, próprio do ECM, é sempre sem especificador (no PBH, houve apenas uma ocorrência de possessivo em um universo de 600 dados, igualmente sem especificador). Ao contrário dos artigos, que não carregam em sua forma nenhuma marcação de pessoa, e ainda ao contrário dos demonstrativos, que tendem a se reduzir a apenas dois termos (indicando talvez somente perto do falante $\times$ fora do espaço falante-ouvinte no caso do ECM), os possessivos, ao menos no ECM, ainda apresentam uma estreita relação aos três participantes do discurso: desconsiderando as flexões de gênero e número, as formas são $m i$ e nuestro para a $1^{\text {a }}$ pessoa de singular e plural respectivamente, $t u$ para a $2^{\mathrm{a}}$ de singular informal, $s u$ [= "de usted/ustedes"] para a $2^{\mathrm{a}}$ de singular formal, a $2^{\mathrm{a}}$ de plural (sem distinção de tratamento) e a $3^{\text {a }}$ de singular ou plural. A existência desse sistema de diferenciação parece tornar desnecessária a adjunção de outro elemento especificador (tal como a de um locativo). A quase ausência de possessivos no $\mathrm{PBH}$ para o contexto em questão parece estar relacionada ao fato de que o paradigma vernacular dos possessivos no PBH não se baseia apenas em determinantes pré-nominais e ao fato de que possui inventário mais reduzido (com menos diferencial formal de significado): cf. meu/nosso ( $1^{\text {a }}$ pessoa, préou pós-nominal $) \times \operatorname{seu}\left(2^{\mathrm{a}}\right.$ pessoa, pré- ou pós-nominal $) \times$ dele ( $3^{\mathrm{a}}$ pessoa, apenas pós-nominal) (CASTILHO, 2010, p. 501-502).

É interessante, por fim, notar que, no ECM, quanto mais informação semântica oferece uma forma (cf., p. ex., os dados com demonstrativos ou possessivos), maior restrição há no sintagma nominal quanto à presença de especificadores.

Com o objetivo de verificar se a tendência de adjunção de locativo se manifesta no sistema de demonstrativos do PBH e do ECM, examinou-se o tipo de especificador presente nos dados. Não entraram nos gráficos a seguir as ocorrências relativas a possessivos porque não ocorreram com especificador no corpus. 
Os dados foram novamente distribuídos em duas categorias: locativos não-oracionais e outros. Consideramos do tipo nãooracional ocorrências como "Dame la pelota de allá (artigo com locativo não-oracional = AL) e "Me dá aquela bola lá" (demonstrativo com locativo não-oracional $=\mathrm{DL}$ ). Consideramos do tipo outros ocorrências como "Me dá $a$ bola que tá ali"/"Dame la pelota que tienes" (artigo com outro tipo de especificador $=\mathrm{AO}$ ) e "Me dá aquela bola que está na sua frente" e "Dame esa pelota que está frente a $t i$ " (demonstrativo com outro tipo de especificador $=\mathrm{DO}$ ). Os valores apurados foram:

\section{TABELA 7}

Frequência por tipo de especificador

\begin{tabular}{l|c|c|c|c}
\hline & AL & AO & DL & DO \\
\hline PBH & $64(57,7 \%)$ & $47(42,3 \%)$ & $162(89,5 \%)$ & $19(10,5 \%)$ \\
\hline Total & \multicolumn{2}{|c|}{$111(100 \%)$} & \multicolumn{2}{c}{$181(100 \%)$} \\
\hline ECM & $25(12,5 \%)$ & $175(87,5 \%)$ & $4(36,4 \%)$ & $7(63,6 \%)$ \\
\hline Total & \multicolumn{2}{|c|}{$200(100 \%)$} & \multicolumn{2}{c}{$11(100 \%)$} \\
\hline
\end{tabular}

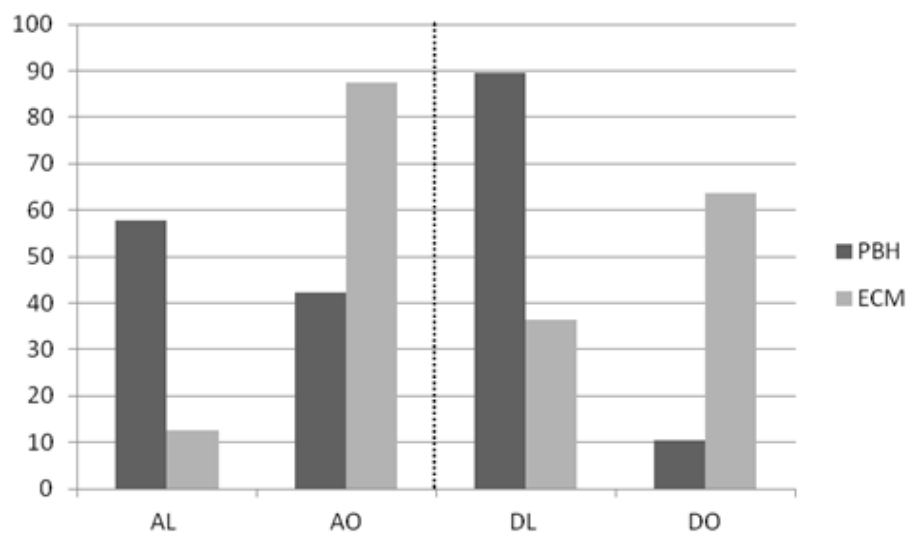

GRÁFICO 8: Frequência (\%) de tipo de especificador

Verifica-se pelo Gráfico 8 que a adjunção de locativos, seja ao artigo (AL) seja ao demonstrativo (DL), é a estratégia preferida pelos falantes do $\mathrm{PBH}$. Sua ocorrência é maior que a soma das 
outras formas de especificação de que se faz uso no português. No caso do ECM, essa estratégia parece não ser produtiva. A soma das outras possibilidades (AO e DO) é significativamente maior que a escolha pela adjunção de locativo. Embora os demonstrativos no PBH e no ECM estejam sofrendo um processo de redução de termos do seu sistema (passando de ternário a binário), as estratégias para compensar a redução parecem ser diferentes para cada língua.

Os dados apresentados nos Gráficos 6, 7 e 8 demonstram que a expressão da dêixis tem como hierarquia básica no $\mathrm{PBH}$ demonstrativo $>$ artigo enquanto no ECM essa hierarquia é artigo $>$ demonstrativo $>$ possessivo. A redução a dois termos no sistema de demonstrativos dessas duas variedades linguísticas parece ter como consequência um remapeamento dêitico: no $\mathrm{PBH}$ haveria uma diferenciação entre dentro espaço falante-ouvinte (expresso pelo uso de F2) e fora do espaço falante-ouvinte (expresso pelo uso de F3); já no ECM o remapeamento seria perto do falante (expresso pelo uso de F1) e distante do falante (expresso pelo uso de F2).

É interessante verificar que, mesmo quando se usa como determinante um artigo no $\mathrm{PBH}$, o recurso à adjunção de locativo se manifesta, dando a entender que contemporaneamente seria essa categoria a que mais prototipicamente mapeia linguisticamente o espaço (físico ou comunicativo). Considerando o caso já citado do francês (com gramaticalização plenamente consumada da adjunção de advérbio locativo) e o caso aqui descrito do $\mathrm{PBH}$, surpreende que no ECM não seja esse o recurso privilegiado. Embora na língua espanhola de forma geral existam cinco advérbios locativos (a saber, acá, aquí, abí, allí e allá), há uma tendência de neutralização entre as formas abi e allí em função da iodização da palatal de allí (MARTÍN BUTRAGUEÑO, 2011). É provavelmente esse fenômeno que deve estar levando os falantes dessa variedade a buscarem outro mecanismo compensatório para segmentar os espaços de mapeamento, pois para o espaço do falante (expresso por F1) é redundante o uso de acá e aquí (que expressa 
perto do falante) e para fora desse espaço (expresso por F2) o uso de abí e allí seria ambíguo em função da neutralização fônica: seu uso não deixaria claro se se trata de algo perto do ouvinte - abíou algo além dos participantes do ato de fala mas não tão distante - allí - como se marca com allá. Ao que parece, o ECM está elegendo como mecanismo compensatório (trata-se apenas de uma tendência) o uso de artigo com especificador oracional (do tipo "Dame la pelota que tienes enfrente"), além de também lançar mão do uso de possessivos (como em "Dame $t u$ pelota"). Nesses dois casos percebe-se como estratégia o uso de elementos mais claros em relação ao vínculo com o participante do ato de fala: no primeiro caso, o vínculo com o ouvinte está expresso pelo morfema de flexão número-pessoal (tiene+s); no segundo caso, pelo possessivo de $2^{a}$ pessoa singular informal $(t u)$. Levando em conta a simplificação do paradigma flexional verbal do português brasileiro (CASTILHO, 2010, p. 208), é possível imaginar por que não se daria preferência pela marca verbal: utiliza-se a mesma forma para $2^{\mathrm{a}}$ e $3^{\mathrm{a}}$ pessoa (cf. você tem $\times$ ele tem), deixando assim de ser distintiva (quando considerada per se).

\section{Conclusões}

Os fenômenos aqui discutidos revelam que os atuais postulados das teorias de gramaticalização e lexicalização exigem reconsiderações.

Primeiramente, a unidirecionalidade da mudança, entendida como irreversibilidade, não deve ser considerada de forma tão categórica, pois a história da sequência demonstrativo + indefinido no português e no espanhol revela existência de processo de lexicalização seguido de antilexicalização. Ainda que reversões possam ser raras, devem receber especial atenção para que as teorias sejam abrangentes o suficiente para dar conta de fatos como esse sem serem considerados como exceções ou necessitarem de explicações ad-boc. Um aspecto essencial para essa discussão 
parece ser a diferenciação entre casos em que a variação entre forma conservadora e inovadora se resolve de forma categórica em favor da inovadora (com desaparecimento da conservadora) e casos em que essa variação nunca chegou a deixar de existir. Ademais, os dados sugerem que a diferenciação entre gramaticalização e lexicalização deve ser menos estanque do que se pensa, já que o processo de lexicalização analisado apresenta traços ora próprios de lexicalização ora de gramaticalização.

Em segundo lugar, as definições de gramaticalização de forma geral parecem negligenciar processos como o de emergência de novos padrões de organização de elementos em uma dada estrutura sintática: também estes devem ser entendidos como gramaticalização na medida em que representam a criação de novos recursos gramaticais. Tal é o caso da gênese da posposição não-articuladade demonstrativo no português e no espanhol: não se trata de um item lexical que se torna gramatical (como é tradicionalmente caracterizada a gramaticalização), mas sim de um processo em que, através de uma reanálise, se criou um novo tipo sintático (demonstrativo posposto) com funções mais específicas do que o padrão até então vigente (demonstrativo anteposto), o qual, por sua vez, continuou como parte do sistema.

Por fim, a unidirecionalidade da mudança, entendida como percurso único, também deve ser repensada. A tendência ao binarismo no sistema de demonstrativos das línguas românicas não parece estar levando necessariamente à gramaticalização da adjunção de advérbios a sintagmas nominais com demonstrativos em todas as variedades linguísticas: embora no português de Belo Horizonte seja o mecanismo compensatório mais produtivo, no espanhol da Cidade do México tem produtividade muito limitada - em ambos os casos, em decorrência de particularidades do sistema de cada variedade (redução do inventário de flexão verbal número-pessoal no português e neutralização fônica de ahí e allí no espanhol)

Não houve aqui a intenção de esgotar a análise de cada um desses três fenômenos (que ainda demandam estudos mais 
aprofundados), mas sim o desejo de evidenciar a relevância deles para uma revisão das teorias de gramaticalização e lexicalização em voga.

\section{Referências}

ALEXANDER, D. B. The Spanish postnominal Demonstrative in synchrony and diachrony. Ohio: Ohio State University, 2007. Tese (Doutorado) - Spanish and Portuguese Graduate Program.

BECHARA, E. Moderna gramática portuguesa. 23. ed. São Paulo: Nacional, 1978.

BRINTON, L. J.;TRAUGOTT, E. C. Lexicalization and language change. Cambridge: Cambridge University Press, 2005.

BRUCART, J. M. El demonstratiu. In: SOLÀ, J. et al.Gramàtica del català contemporani. 4. ed.(edició definitiva). Barcelona: Empúries, 2008. Vol. 2, p. 1490-1496. [1. ed., 2002].

CÂMARA JR., J. M. Uma evolução em marcha: a relação entre êste e êsse. In: COSERIU, E.; STEMPEL, W.-D. (Org.). Sprache und Geschichte: Festschrift für Harri Meier zum 65 Geburtstag. München: Wilhelm Fink, 1971. p. 327-331.

CAMBRAIA, C. N. Assimetrias românicas: espanhol nosotros/vosostros e catalão nosaltres/vosaltres $\times$ português nós (outros) / vós (outros). Caligrama, Belo Horizonte, v. 10, p. 7-30, 2005.

CAMBRAIA, C. N. Demonstrativos na România Nova: português brasileiro $\times$ espanhol mexicano (dados de diálogos entre informante e documentador). Caligrama, Belo Horizonte, n. 14, p. 7-34, 2009.

CAMBRAIA, C. N. Demonstrativo + indefinido outro na bistória da língua portuguesa: (des)gramaticalização ou (des)lexicalização? Belo Horizonte, 2010. (Comunicação apresentada no Workshop Internacional sobre Gramaticalização, em Belo Horizonte, no período de 26 a 27 de agosto de 2010).

CAMBRAIA, C. N.; BIANCHET, S. M. G. Caleidoscópio latino-românico: demonstrativos. Cadernos de Letras da UFF, Niterói, n. 35, p. 15-36, 2008. 
CASTILHO, A. T. Nova gramática do português brasileiro. São Paulo: Contexto, 2010.

CUNHA, C.; CINTRA, L. F. L. Nova gramática do português contemporâneo. 2. ed. 5. reimpr. Rio de Janeiro: Nova Fronteira, 1985

DAVIES, M. Corpus del español (100 millones de palabras, siglo XIII siglo $X X) .2002$ [http://www.corpusdelespanol.org].

FARIA, E. Gramática superior da língua latina. Rio de Janeiro: Acadêmica, 1968.

FERREIRA, M. Corpus do português (45 milhões de palavras, sécs. XIV$X X) .2006$ [http://www.corpusdoportugues.org]

GIVÓN, T. Syntax: an introduction. Amsterdam/Philadelphia: John Benjamins, 2001. 2. v.

GONZÁLEZ ÁlVAREZ, E. A. del S. C. de J. Usos de los demostrativos en las hablas culta y popular de la Ciudad de México. México: Universidad Nacional Autónoma de México, 2006. (Master en Letras: Linguística Hispánica)

HOPPER, P. J.; TRAUGOTT, E. C. Gramaticalization. Cambridge: Cambridge University Press, 1993.

JUNGBLUTH, K. Pragmatik der Demonstrativpromina in den iberoromanischen Sprachen. Tübingen: Max Niemeyer, 2005.

KANY, C. E. Sintaxis hispaoamericana. 2. reimpr. Madrid: Gredos, 1994.

LLORACH, E. A. Gramática de la lengua española. Madrid: Espasa Calpe, 2000.

LLOYD, P. Del latín al español: I. Fonología y morfología históricas de la lengua española. Madrid: Gredos, 1989.

MARTÍN BUTRAGUEÑO, P. Dialectología de nuevos mundos: una lectura variacionista del Atlas Lingüístico de México. In: Selected Proceedings of the 13th Hispanic Linguistics Symposium, ed. Luis A. Ortiz-López, 17-32. Somerville, MA: Cascadilla Proceedings Project, 2011.

MILANO, F. da. Demonstratives in the languages of Europe. In: RAMAT, P.; ROMA, E. (Ed.). Europe and the Mediterranean as linguistic areas: convergences from a bistorical and typological perspective. Amsterdam: John Benjamins, 2007. p. 25-47. 
NARO, A. J.; LEMLE, M. Syntactic diffusion. Ciência e Cultura, São Paulo, v. 29, n. 3, p. 259-268, 1977.

PAVANI, S. Os demonstrativos este, esse e aquele no português culto falado em São Paulo. 1987. Dissertação (Mestrado em Linguística) UNICAMP, Campinas.

POPESCU, A. Gramatica practică a limbii române. Bucureti: Exigent, 2006.

RAMALHO, V. H. B. Posposição de demonstrativos no português e no espanbol: estudo histórico e comparado das estruturas articuladas e não-articuladas. Dissertação (Mestrado em Estudos Linguísticos) Faculdade de Letras da UFMG, Belo Horizonte. Em preparação.

ROCA URGELL, F. La determinación y la modificación nominal en español. (Tese de doutorado) - Facultat de Filosofia i Lletres/ Universitat Autònoma de Barcelona, Barcelona, 1996.

RONCARATI, C. Os mostrativos na variedade carioca falada. In: PAIVA, M. da C.; DUARTE, M. E. L. (Org.) Mudança lingüística em tempo real. Rio de Janeiro: Contra Capa, 2003. p. 139-157.

STRADIOTO, S. A. Dêixis na România Nova: o lugar dos demonstrativos no português de Belo Horizonte e no espanbol da Cidade do México. Dissertação (Mestrado em Estudos Linguísticos) - Faculdade de Letras da UFMG, Belo Horizonte. Em preparação.

WILLIAMS. Do latim ao português: fonologia e morfologia históricas da língua portuguesa. 4. ed. Rio de Janeiro: Tempo Brasileiro, 1991.

Recebido para publicação em 31 de agosto de 2011. Aprovado em 29 de outubro de 2011. 